\title{
Regression analysis of the impact of internal factors on return on assets: a case of meat processing enterprises in Serbia
}

\author{
Stojanka Dakić \\ University of Novi Sad, Faculty of Economics in Subotica, Republic of Serbia \\ Kristina Mijić \\ University of Novi Sad, Faculty of Economics in Subotica, Republic of Serbia
}

\begin{abstract}
The aim of this paper is to identify and measure the impact of internal factors on the business success of meat processing enterprises expressed through profitability. Panel analysis was constructed for the sample which includes 24 enterprises in Serbia at the period from 2007 to 2016 . The accounting rate of Return on assets (ROA), as a measure of productivity, was in function of the dependent variable, while the size of the enterprise, age, debt ratio, quick ratio, inventory, sale growth and capital turnover ratio were found as independent variables. A regression model was constructed and indicated that most variables had a statistically significant influence on the dependent variable. This kind of results are very important for potential investors. They can help them to better understand impact of internal factors on profitability and make better decisions about investment in this sector.
\end{abstract}

Keywords

Regression, profitability, ROA, meat processing enterprises

\section{Introduction}

The main goal of every enterprise is long-term business. In order to achieve that, enterprises must realize business activities successfully. Business success is usually measured by profitability. "Critical success factors answer the question about what drives growth, profitability, and success in company. It is important for managers to understand the dynamics of the factors that drive profitability, and growth to take advantage of them to improve their competitive position. Critical success factors as any other strategic model is iterative and dynamic, managers who can use strategic models dynamically, creatively, and competitively will achieve superior performance" (Tadić, Jevtić \& Jančev, 2019).
Profitability, as ability to gain earn on investment, is a key prerequisite for the growth and development of a business and the achievement of its core business goal. High profitability is the primary goal of every business, regardless of its size, method of financing, ownership and other internal or external factors that in many ways affect the achievement of this goal.

Besides continuously measuring profitability, management of enterprises must identify which factors have significant influence on profitability. Factors can have significant positive or negative influence on enterprises profitability.

Analyses of profitability and its significant factor provide the profile of enterprises success which can be useful for a wide range of financial statements users. 
The aim of this paper is to analyze profitability factors of meat processing enterprises in the Republic of Serbia. The meat processing industry is one of the major industry for providing food safe supply and reducing import dependency.

The research is based on financial statements of meat processing enterprises for a period 20072016. The data was collected from the Scoring database (Scoring, 2019).

\section{Literature review}

Profitability and factors of profitability are investigated by many authors using different methodological approaches.

The profitability of 137 Turkish listed manufacturing enterprises was analysed by Coban (2014). The research was based on the panel data and system-GMM. The results showed that there is a statistically significant positive relation between current profit and current growth.

McDonald (1999) analysed the profitability factors of the Australian manufacturing enterprises for the period 1984-1993. The results indicate that lagged profitability and industry affiliation are the crucial factors of profitability.

The determinants of profitability in food sector in Pakistan was research by multivariate regression analysis (Nousheen \& Arshad, 2013) in the period 2002-2006. The results show significant negative relationship between size and profitability. Furthermore, tangibility, growth and food inflation are insignificantly positively related to profitability. Debt to equity ratio has negative insignificant influence on profitability.

Dogan (2013) investigated the profitability factors of 200 companies listed on Istanbul Stock Exchange for the period 2008-2011 by using multiple regression and correlation methods. The result of analysis indicates a positive relation between size indicators and profitability of firms. Control variables as the age of the firms and leverage rate have been found in a negative relation with ROA, but liquidity rate and ROA have been determined to have a positive relation.

Multiple linear regression and the Karl Pearson Correlation Coefficient were used to analyze profitability determinants of agricultural firms listed at the Nairobi Securities Exchange in Kenya (Collins, 2016). The results show that that there is a positive and statistically significant relationship between liquidity, firm size and profitability, whereas there is a significant negative relationship between tangibility and profitability.

The impact of internal factors on profitability of agricultural sectors of countries of CEE region for the period 2011-2014 was investigate by using a panel data estimation technique (Mijic \& Jaksic, 2017). The results show that profitability of agricultural sector in Hungary and Romania is positively related to quick ratio, debt ratio, sales growth and lagged profitability. Companies' size and fixed assets to total assets ratio have negative impact on profitability. Profitability determinants of agricultural sectors in Serbia and Bosnia and Herzegovina are similar. In both countries, profitability of agricultural industry are positively related to the quick ratio, lagged profitability and growth, while in Bosnia and Herzegovina leverage is also significant.

\section{Data and methodology}

According to Levinthal (1995), the analysis of business performance differences is the basic mission of strategic management.

In this regard, the aim of this paper is to indirectly explain the sources of the above mentioned differences through the identification and measurement of internal factors that influence the success of the business of the company.

The subject of the research was to determine the way in which internal business factors demonstrate the impact on the performance of enterprises measured by productivity.

The regression model has determined the direction of this influence (positive / negative), the strength of effect (lower / higher coefficient) and the statistical significance of the impact.

In accordance with the aim of the research and after a detailed analysis of the research studies in the subject area, the following hypothesis was set up:

$\mathrm{H}_{1}$ : Internal factors, such as size of company, age, debt ratio, quick ratio, inventory, sale growth and capital turnover ratio, have a significant influence on profitability (measured by return on assets) of meat processing enterprises in Serbia.

The original sample consisted of 34 meat processing enterprises, but in order to build a balanced panel model, the final sample covered 24 enterprises that were observed in the period 20072016 (10 years). The source of data was the Agency for Business Registers of the Republic of Serbia.

The business success of selected enterprises in survey is measured by its profitability. Return on assets (ROA - Return on Assets) is an often used profitability indicator in analysis and it is more appropriate profitability indicator than Return on 
Equity (ROE) because "the return on equity wouldn't provide a good comparison because the small and the negative equity levels of some enterprises would generate distorted indicators of profitability" Vieira (2010).

For these reasons, ROA was selected as the dependent variable in the regression model.

List of other variables used in regression model is given in Table 1.

Table1 List of variables

\begin{tabular}{|c|c|c|}
\hline Variables & Indicator & Explanation \\
\hline \multicolumn{3}{|c|}{ Dependent } \\
\hline $\begin{array}{l}\text { Return on } \\
\text { assets } \\
\text { (ROA) }\end{array}$ & $\begin{array}{l}\text { Indicates } \\
\text { company's } \\
\text { ability to } \\
\text { generate profit } \\
\text { from its assets. }\end{array}$ & $\begin{array}{l}\text { ROA=Net } \quad \text { Income } \\
\text { Margin x Assets } \\
\text { Turnover } \\
\text { Net Income Margin=Net } \\
\text { Income/Sales } \\
\text { Assets } \\
\text { Turnover=Sales/Total } \\
\text { Assets }\end{array}$ \\
\hline \multicolumn{3}{|c|}{ Explanatory } \\
\hline \multicolumn{3}{|l|}{ Size } \\
\hline \multicolumn{3}{|l|}{ Age } \\
\hline Debt ratio & $\begin{array}{l}\text { Measures the extent } \\
\text { of a company's } \\
\text { leverage. }\end{array}$ & $\begin{array}{ll}\text { Debt ratio= } & \text { Total } \\
\text { debts } / & \text { Total } \\
\text { Assets } & \end{array}$ \\
\hline Quick ratio & $\begin{array}{l}\text { Company's short-term } \\
\text { liquidity indicator }\end{array}$ & $\begin{array}{l}\text { Quick ratio = } \\
\text { (current assets - } \\
\text { inventories) } \\
\text { current liabilities }\end{array}$ \\
\hline Inventory & $\begin{array}{l}\text { The most important } \\
\text { assets of a business } \\
\text { because the turnover } \\
\text { of inventory } \\
\text { represents one of the } \\
\text { primary sources of } \\
\text { income generation } \\
\text { and following earnings } \\
\text { for the company's } \\
\text { shareholders. }\end{array}$ & \\
\hline $\begin{array}{l}\text { Sale } \\
\text { growth }\end{array}$ & $\begin{array}{l}\text { Percentage increase } \\
\text { (decrease) in sales } \\
\text { between two time } \\
\text { periods. }\end{array}$ & $\begin{array}{l}\text { Sales Growth = } \\
\text { Current Period - } \\
\text { Previous Period } \\
\text { Sales }\end{array}$ \\
\hline $\begin{array}{l}\text { Capital } \\
\text { turnover } \\
\text { ratio }\end{array}$ & $\begin{array}{l}\text { Indicates the } \\
\text { efficiency of the } \\
\text { organization with } \\
\text { which the capital } \\
\text { employed is being } \\
\text { utilized. }\end{array}$ & $\begin{array}{l}\text { Capital turnover } \\
\text { ratio = Sales/ } \\
\text { Capital Employed }\end{array}$ \\
\hline
\end{tabular}

Source: Authors illustration (based on Chandrapala and Knapkova 2013; Bhutta and Hassan, 2013; Nuševa, Mijić, Jakšić, 2017).

In order to analyse the influence of internal factors on the profitability of meat production enterprises in Serbia, the following general model was used:

$$
y_{t t}=\alpha+\beta_{t i t} x_{t t}+u_{t t}
$$

where $i$ is a subscript for observation $(i=1, \ldots$, $\mathrm{N})$ and $t$ for time $(t=1, \ldots, \mathrm{T}), \quad x$ represents the dependent variable, the $\alpha$ tag for the cut, $\beta$ is $\mathrm{k} \mathrm{x} 1$ parameter vector which needs to be evaluated on independent variables, represents $1 \mathrm{x} \mathrm{k}$ vector observations on independent variables and represents the mark for a random error (Brooks, 2008).

By incorporating internal variables into the previous equation, we obtain a model that evaluates the impact of internal factors on the profitability of selected enterprises:

$$
R O A_{i t}=\alpha_{i t}+\beta_{1} \text { size }_{i t}+\beta_{2} a_{g e}+
$$

$\beta_{3}$ debt_ratio $_{i t}+\beta_{4}$ quick_ratio $_{i t}+$ $\beta_{5}$ inventory $_{i t}+\beta_{6}$ sale_growth $_{i t}+$ $\beta_{7}$ capital_turnover_ratio $i t+u_{i t}$

Where $i$ is a subscript for observation $(I=1, \ldots, 24)$ and $t$ for time $(t=1, \ldots, 10)$.

\section{Empirical results and discussion}

Information about the descriptive parameters for the variables involved in survey are presented in Table 2.

Table 2 Descriptive statistics (240 observations)

\begin{tabular}{c|r|r|r|l}
\hline Variable & \multicolumn{1}{|c|}{ Mean } & \multicolumn{1}{c}{ Minimum } & Maximum & $\begin{array}{l}\text { Std. } \\
\text { Dev. }\end{array}$ \\
\hline ROA & 0.0686 & -0.3179 & 0.4869 & 0.0914 \\
\hline Size & 5.5015 & 3.4116 & 7.1951 & 0.7950 \\
\hline Age & $\begin{array}{r}18.658 \\
3\end{array}$ & 10 & 46 & 7.8201 \\
\hline Debt ratio & 0.6532 & 0.1647 & 0.9713 & 0.2074 \\
\hline Quick ratio & 1.0019 & 0.13 & 5.16 & 0.6769 \\
\hline $\begin{array}{c}\text { Inventory } \\
\text { Aale } \\
\text { growth }\end{array}$ & 0.1742 & 0 & 0.5795 & 0.1165 \\
\hline $\begin{array}{c}\text { Capital } \\
\text { turnover } \\
\text { ratio }\end{array}$ & 0.3269 & 0.0162 & 1.2633 & 0.2560 \\
\hline
\end{tabular}

Source: The authors

Most theorists agree that a good level of profitability is when a ROA is higher than $10 \%$. As we can see in Table 2, the average ROA on the example of selected meat production and processing enterprises in the observed period of 10 years amounts to $6.86 \%$, which can be considered as a low level of profitability.

Before forming a regression model, it is necessary to examine the correlation between the observed independent variables in order to discover the possible problem of multicolinearity which can cause disorders in estimating the value 
of parameters, their significance and the direction of influence on the dependent variable.

Correlation matrix shows coefficients of correlation between pairs of potential independent variables and it is often used method for perceiving the problem of multicolinearity in panel models.

Correlation matrix is displayed in Table 3.

Table 3 Correlation matrix

\begin{tabular}{|c|c|c|c|c|c|c|c|c|}
\hline & $\begin{array}{l}R O \\
A\end{array}$ & $\begin{array}{l}\text { Siz } \\
e\end{array}$ & $\begin{array}{l}A g \\
e\end{array}$ & $\begin{array}{l}\text { Deb } \\
t \\
\text { ratio }\end{array}$ & $\begin{array}{l}\text { Qui } \\
\text { ck } \\
\text { ratio }\end{array}$ & $\begin{array}{l}\text { Inve } \\
\text { ntory }\end{array}$ & $\begin{array}{l}\text { Sal } \\
e \\
\text { gro } \\
\text { wh }\end{array}$ & $\begin{array}{l}\text { Cap } \\
\text { ital } \\
\text { turn } \\
\text { over } \\
\text { ratio }\end{array}$ \\
\hline$R O A$ & $\begin{array}{l}1.0 \\
000\end{array}$ & & & & & & & \\
\hline Size & $\begin{array}{c}- \\
0.1 \\
051\end{array}$ & $\begin{array}{l}1.0 \\
000\end{array}$ & & & & & & \\
\hline Age & $\begin{array}{c}- \\
0.1 \\
823\end{array}$ & $\begin{array}{c}0.4 \\
825\end{array}$ & $\begin{array}{c}1.0 \\
00 \\
0\end{array}$ & & & & & \\
\hline $\begin{array}{l}\text { Debt } \\
\text { ratio }\end{array}$ & $\begin{array}{c}- \\
0.4 \\
431\end{array}$ & $\begin{array}{c}- \\
0.3 \\
547\end{array}$ & $\begin{array}{c}- \\
0.2 \\
14 \\
8\end{array}$ & $\begin{array}{r}1.0 \\
000\end{array}$ & & & & \\
\hline $\begin{array}{l}\text { Quic } \\
k \\
\text { ratio }\end{array}$ & $\begin{array}{c}0.3 \\
844\end{array}$ & $\begin{array}{c}- \\
0.1 \\
143\end{array}$ & $\begin{array}{c}0.0 \\
31 \\
0\end{array}$ & $\begin{array}{c}- \\
0.49 \\
52\end{array}$ & $\begin{array}{r}1.0 \\
000\end{array}$ & & & \\
\hline $\begin{array}{l}\text { Inve } \\
\text { ntory }\end{array}$ & $\begin{array}{c}- \\
0.0 \\
193\end{array}$ & $\begin{array}{l}0.0 \\
061\end{array}$ & $\begin{array}{c}- \\
0.1 \\
29 \\
2\end{array}$ & $\begin{array}{r}0.1 \\
086\end{array}$ & $\begin{array}{c}- \\
0.30 \\
99\end{array}$ & $\begin{array}{l}1.00 \\
00\end{array}$ & & \\
\hline $\begin{array}{l}\text { Sale } \\
\text { grow } \\
\text { th }\end{array}$ & $\begin{array}{r}0.0 \\
919\end{array}$ & $\begin{array}{c}- \\
0.2 \\
216\end{array}$ & $\begin{array}{c}- \\
0.1 \\
33 \\
5\end{array}$ & $\begin{array}{l}0.15 \\
97\end{array}$ & $\begin{array}{c}- \\
0.10 \\
25\end{array}$ & $\begin{array}{c}- \\
0.03 \\
31\end{array}$ & $\begin{array}{l}1.00 \\
00\end{array}$ & \\
\hline $\begin{array}{l}\text { Capi } \\
\text { tal } \\
\text { turn } \\
\text { over } \\
\text { ratio }\end{array}$ & $\begin{array}{c}- \\
0.1 \\
582\end{array}$ & $\begin{array}{r}0.6 \\
285\end{array}$ & $\begin{array}{c}0.4 \\
24 \\
8\end{array}$ & $\begin{array}{c}- \\
0.39 \\
02\end{array}$ & $\begin{array}{c}- \\
0.07 \\
32\end{array}$ & $\begin{array}{c}- \\
0.10 \\
30\end{array}$ & $\begin{array}{c}- \\
0.20 \\
75\end{array}$ & $\begin{array}{r}1.0 \\
000\end{array}$ \\
\hline
\end{tabular}

All values of correlation coefficients are not at a level that could lead to multicolinearity problems.

In multiple regression analysis, the variance inflation factor (VIF) is often used as indicators of multicolinearity.

Acceptable level of tolerance value is 10 and it is recommended as the maximum level of tolerance. Since all VIF values are less than 10 (see Table 4), it is concluded that there is no multicolinearity between the variables.
Table 4 Colinearity statistics

\begin{tabular}{l|c}
\hline \multicolumn{1}{c|}{ Variable } & VIF \\
\hline Size & 2.011 \\
\hline Age & 1.378 \\
\hline Debt ratio & 1.898 \\
\hline Quick ratio & 1.793 \\
\hline Inventory & 1.171 \\
\hline Sale growth & 1.089 \\
\hline Capital turnover ratio & 1.929 \\
\hline
\end{tabular}

The question "Which model to choose" is frequently raised when conducting empirical research.

The selection of appropriate model between the pooled OLS and fixed effect is based on the joint significance of differing group means, which is used to test null hypothesis that the pooled OLS model is adequate. A low p-value means that fixed effects model is more appropriate then the pooled OLS model.

Breusch-Pagan test is often used for the selection between the pooled OLS and random effects model. A low p-value means that random effects model is more appropriate then the pooled OLS model.

The selection of appropriate model between random effect and fixed effect is based on the Hausman test which is used to test null hypothesis that the random effect model is adequate and more appropriate then the fixed effect.

Panel model diagnostics is given in Table 5.

Table 5 Panel model diagnostic (assuming a balanced panel with 24 cross-sectional units observed over 10 periods)

\begin{tabular}{|c|c|c|c|}
\hline Diagnostics & $\begin{array}{l}\text { Asymptotic } \\
\text { test statistic }\end{array}$ & $p$-value & Decision \\
\hline $\begin{array}{l}\text { Joint } \\
\text { significance } \\
\text { of differing } \\
\text { group means: }\end{array}$ & $\begin{array}{l}F(23,209)= \\
0.77911\end{array}$ & 0.755 & $\begin{array}{l}\text { The pooled } \\
\text { OLS model is } \\
\text { more } \\
\text { appropriate } \\
\text { than the fixed } \\
\text { effects } \\
\text { alternative. }\end{array}$ \\
\hline $\begin{array}{l}\text { Breusch- } \\
\text { Pagan test } \\
\text { statistic }\end{array}$ & $\begin{array}{l}\text { Chi- } \\
\text { square }(1)= \\
0.872518\end{array}$ & 0.350 & $\begin{array}{l}\text { The pooled } \\
\text { OLS model is } \\
\text { more } \\
\text { appropriate } \\
\text { than the } \\
\text { random } \\
\text { effects } \\
\text { alternative. }\end{array}$ \\
\hline
\end{tabular}

Source: The authors

After providing all assumptions, the pooled OLS model is performed. The coefficients estimations are given in Table 6. 
Table 6 Pooled OLS model

\begin{tabular}{|c|c|c|c|c|}
\hline Variables & Coefficient & Std. Error & t-ratio & $p$-value \\
\hline const & 0.2798 & 0.0584 & 4.783 & $<0.00001^{* * *}$ \\
\hline Size & -0.0025 & 0.0084 & -0.303 & 0.76144 \\
\hline Age & -0.0019 & 0.0007 & -2.724 & $0.00692^{\star \star \star}$ \\
\hline Debt ratio & -0.2413 & 0.0316 & -7.629 & $<0.00001^{* \star \star}$ \\
\hline Quick ratio & 0.0161 & 0.0094 & 1.713 & $0.08792^{*}$ \\
\hline Inventory & 0.0264 & 0.0442 & 0.598 & 0.55015 \\
\hline Sale growth & 0.0301 & 0.0144 & 2.086 & $0.03805^{\star \star}$ \\
\hline $\begin{array}{l}\text { Capital turnover } \\
\text { ratio }\end{array}$ & -0.0897 & 0.0258 & -3.472 & $0.00062^{\star * *}$ \\
\hline R-squared & & 0.370765 & $\begin{array}{l}\text { Adjusted R- } \\
\text { squared }\end{array}$ & 0.351779 \\
\hline $\mathrm{F}(7,232)$ & & 19.52881 & P-value(F) & 0,0000 \\
\hline Log-likelihood & & 289.5504 & $\begin{array}{l}\text { Akaike } \\
\text { criterion }\end{array}$ & -563.1007 \\
\hline $\begin{array}{l}\text { Schwarz } \\
\text { criterion }\end{array}$ & & -535.2556 & $\begin{array}{l}\text { Hannan- } \\
\text { Quinn }\end{array}$ & -551.8812 \\
\hline rho & & -0.052180 & $\begin{array}{l}\text { Durbin- } \\
\text { Watson }\end{array}$ & 1.959131 \\
\hline
\end{tabular}

Based on the results of the panel analysis (Table 6), it can be concluded that most variables included in model are statistically significance. Variables age (-0.0019), debt ratio (-0.2413) and capital turnover ratio (-0.0897) are statistically significant at the level of significance of $1 \%$, the variable sale growth is statistically significant at the level of significance of $5 \%$ and the variable quick ratio (0.0161) is statistically significant at the level of significance of $10 \%$. Other variables have not a statistically significant impact on the dependent variable, which means that the null hypothesis was partially accepted.

\section{Conclusion}

"The default of companies is the problem of every economy in the world. Defaults can have various forms, various manifestations and consequences. In particular, the consequences are the engine of research and development of methods and models that help predict the failure in advance. Prediction models are used for an early detection of impending problems in the analysed company" (Valaskova, Kliestik \& Kovacova, 2018).

The basic idea of this research was to apply the methodology in the field of panel data analysis to the developed statistical model that includes various internal factors, as determinants of business success of the company. The statistical tests which were applied confirm the assumption that using panel models it is possible to identify factors that affect the profitability of manufacturing companies in Serbia.

Food processing industry in the Republic of Serbia is very important in order to provide safe food supply. Furthermore, development of food processing industry provide reducing import dependency of food supply. Food processing companies have in average positive profitability. For the period 2007-2016 an average profitability rate is 0.0686 which means that 6.86 percent of assets companies retain as net income.

The research results indicate that quick ratio and sales growth have significant positive impact on profitability of enterprises in food processing industry. Earlier research has shown that if a manufacturing company increases sales of its products, it does not mean that it will increase its profitability, since sales growth can at the same time be accompanied by an increase in company costs. This leads us to the conclusion that sales growth will only affect profitability if cost-cutting is taken into account.

On the other side, age, debt ratio and capital turnover have significant negative impact on return on assets. Furthermore, the results show that size and inventory have insignificant influence on profitability of food processing enterprises.

A number of internal factors affect the success of a business. Identifying these factors can significantly improve a company's business results. It is the responsibility of the company management to recognize the influence of internal and external factors on the business results of the company and make business decisions and take actions for profit accordingly, as the ultimate goal of the business. The results of research can be useful for many internal and external users of financial statements of food processing companies in order to realize an adequate business decisions.sm

\section{References}

Bhutta, N. \& Hassan, A. (2013). Impact of Firm Specific Factors on Profitability of Firms in Food Sector. Open Journal of Accounting, 02. 19-25.

http://doi.org/10.4236/ojacct.2013.22005

Brooks, C. (2008). Introductory econometrics for finance. New York, USA: Cambridge University Press. https://doi.org/10.1017/CBO9780511841644

Chandrapala, P. \& Knapkova, A. (2013). Firm-specific factors and financial performance of firms in the Czech Republic. Acta Universitatis Agriculturae et Silviculturae Mendelianae $\quad 61.2183-2190$. http://doi.org/10.11118/actaun201361072183

Coban, S. (2014). The interaction between firm growth and profitability: evidence from Turkish (listed) manufacturing firms. Bilgi Economisi ve Yoneimi Dergisi, 9 (2), 73-82. 
Collins, K. (2016). Determinants of profitability of agricultural firms listed at the Nairobi securities exchange, Kenya. International Journal of Economics, Commerce and Management, 4 (9). 225-235.

Dogan, M. (2013). Does Firm Size Affect The Firm Profitability? Evidence from Turkey. Research Journal of Finance and Accounting. 4 (4). 53-59. https://doi.org/10.4236/ojacct.2013.22005

Levinthal, D. (1995). Strategic management and the exploration of diversity. In: Resource-based and evolutionary theories of the firm, Montgomery, C. (Ed.), pp. 19-42, Kluwer, Boston, MA https://doi.org/10.1007/978-1-4615-2201-0 2

McDonald, J. (1999). The determinants of firm profitability in Australian manufacturing. The Economic Record, 75 (229), $115-126$ https://doi.org/10.1111/j.1475-4932.1999.tb02440.x

Mijic, K., \& Jaksic, D. (2017). The determinants of agricultural industry profitability: evidence from southeast Europe. Custos e Agronegocio on line, 13 (1), 154-173.

Nuseva, D., Mijic, K. \& Jaksic, Dejan. (2017). The performances of coffee processors and coffee market in

\section{$\square$ Correspondence}

\section{Stojanka Dakić}

Faculty of Economics in Subotica

University of Novi Sad

Segedinski put 9-11, 24000, Subotica, Serbia

E-mail: stojankad@ef.uns.ac.rs the Republic of Serbia. Economics of Agriculture, 64 307-322.

https://doi.org/10.5937/ekoPolj1701307N

Nousheen, T. B., \& Arshad, H. (2013). Impact of Firm Specific Factors on Profitability of Firms in Food Sector. Open Journal of Accounting, n.2013, 19-25.

Scoring. (2019). Database. Retrieved on May 20th 2019 from http://www.scoring.rs

Tadić, J.,Jevtić, J. \& Jančev, N. (2019). Modeling of critical profitability factors: Empirical research from food industry in Serbia. Economics of Agriculture, 66. 411-422. https://doi.org/10.5937/ekoPolj1902411T

Valaskova, K., Kliestik, T. \& Kovacova, M. (2018). Management of financial risks in Slovak enterprises using regression analysis. Oeconomia Copernicana, 9(1), 105-121. https://doi.org/10.24136/oc.2018.006

Vieira, R. S. (2010). The relationship between liquidity and profitability: An exploratory study of airline enterprises between 2005 and 2008. Umeå University, Master Thesis, Sweden. 